\title{
Labyrinthe
}

2| 1999

Numéro 2

\section{Les conditions de la vie}

Entretien

\section{Guy Ourisson}

\section{(2) OpenEdition}

Journals

Electronic version

URL: http://journals.openedition.org/labyrinthe/349

DOI: $10.4000 /$ labyrinthe.349

ISSN: 1950-6031

\section{Publisher}

Hermann

\section{Printed version}

Date of publication: 15 January 1999

Number of pages: 10-18

\section{Electronic reference}

Guy Ourisson, "Les conditions de la vie », Labyrinthe [Online], 2 | 1999, Online since 04 March 2005 connection on 22 April 2019. URL : http://journals.openedition.org/labyrinthe/349; DOI : 10.4000/ labyrinthe.349

This text was automatically generated on 22 April 2019

Propriété intellectuelle 


\section{Les conditions de la vie}

Entretien

Guy Ourisson 